\title{
Gambaran Pelayanan Konseling Gizi dan Olahraga pada Pasien Diabetes Melitus Tipe 2 di Puskesmas Kota Bandung
}

\author{
Faizah Rofi ${ }^{1}$, Elsa Pudji Setiawati², Siska Wiramihardja² \\ ${ }^{1}$ Fakultas Kedokteran, Universitas Padjadjaran \\ ${ }^{2}$ Departemen Ilmu Kesehatan Masyarakat, Fakultas Kedokteran Universitas Padjadjaran
}

\begin{abstract}
Abstrak
Konseling gizi dan olahraga pada pasien DM Tipe 2 ( DMT2 ) diperlukan untuk mengontrol glukosa darah. Penelitian ini dilakukan untuk mengetahui gambaran keberlangsungan program pelayanan konseling gizi dan olahraga pada pasien DMT2 di Puskesmas Kota Bandung. Penelitian deskriptif kualitatif dilakukan dari bulan Agustus-November 2016 di tiga Puskesmas Kota Bandung. Responden penelitian terdiri dari 3 dokter umum, 3 ahli gizi, dan 18 pasien DMT2. Data diambil dengan wawancara mendalam dan observasi. Alur konseling meliputi pendaftaran, pemeriksaan, cek laboratorium, dan pemeriksaan kembali oleh dokter disertai konseling yang kemudian pasien disarankan untuk rujukan ke ahli gizi dan mengikuti Prolanis. Proses konseling gizi oleh ahli gizi meliputi inisiasi, pengkajian, diagnosis gizi, intervensi, dan evaluasi. Berdasarkan wawancara yang dilakukan dari 24 responden, 18 responden menyatakan konseling gizi oleh dokter dilakukan tanpa tahapan diagnosis gizi. Konseling olahraga meliputi pengkajian dan intervensi olahraga memenuhi 2 dari 7 protokol konseling olahraga. Pengetahuan dokter mengenai penyakit DM lebih lengkap dibandingkan ahli gizi. Fasilitas konseling meliputi ruangan dan food model telah tersedia. Konseling gizi dan olahraga pada pasien diabetes melitus tipe 2 oleh petugas kesehatan telah diimplementasikan di Puskesmas Kota Bandung tetapi masih perlu ditingkatkan karena faktor-faktor berupa faktor dari pasien, petugas kesehatan, dan prosedur.
\end{abstract}

Kata Kunci : Diabetes melitus tipe 2, konseling

\section{Overview of Nutrition and Physical Activity Counseling Services in Diabetes Mellitus Type 2 Patients at Public Health Center Kota Bandung}

\begin{abstract}
Nutrition and physical activity counseling in Diabetes Mellitus Type 2 by health workers is needed to control the blood glucose level. This research was conducted to find out the overview of the nutrition counseling and physical exercise program sustainability in DM type 2 patients in Puskesmas Kota Bandung. This is a descriptive qualitative research that's conducted from August-November 2016 in 3 Puskesmas Kota Bandung. There were 24 respondents consisted of patients, physicians, and nutritionists. The data were collected via in-depth interview and observation. Steps in counseling process consist of registration, doctor examination, laboratorium test, and then back to doctor to be given counseling and referral to nutritionists and Prolanis. The nutrition counseling by nutritionists was going according to the standards, which are: counseling basics building, assessment, nutrition diagnosis, intervention, and evaluation. Meanwhile nutrition counseling by physician was done without the nutrition diagnosis. Physical activity counseling covers physical activity assessment and intervention which fulfilled 2 of 7 physical counseling protocols. The knowledge of doctors about Diabetes Mellitus is more comprehensive than nutrinionists. Counseling facilities like room and food model are already available in Puskesmas Kota Bandung. Nutrition and physical exercise counseling in diabetes mellitus type 2 patients by health workers is already implanted in Puskesmas Kota Bandung but an improvement is still needed due to some factors like patient's factor, health worker's factor, procedure's factor.
\end{abstract}

Keywords : Counseling, type 2 Diabetes mellitus

Korespondensi:

Faizah Rofi

Fakultas Kedokteran Universitas Padjadjaran

Jl. Raya Bandung-Sumedang KM 21 Jatinangor, Sumedang

Mobile : 087726060916

Email : roffaym@gmail.com 


\section{Pendahuluan}

Diabetes Melitus (DM) adalah penyakit metabolik yang ditandai oleh peningkatan kadar glukosa darah. ${ }^{1}$ Populasi DM di dunia meningkat hampir 13 kali lipat dalam dua dekade terakhir dan lebih $60 \%$ dari total populasi tersebut berada di negara negara Asia. Total populasi DM pada tahun 2015 di Indonesia adalah 10 juta pasien. ${ }^{2,3}$ Jawa Barat termasuk dalam 10 provinsi dengan prevalensi DM tertinggi di Indonesia. Pada tahun 2030 diperkirakan akan ada 12 juta pasien DM di daerah urban dan 8,1 juta pasien di daerah rural. Kota Bandung adalah termasuk sebagai daerah urban dengan prevalensi DM tinggi. Diabetes Melitus termasuk dalam 20 penyakit terbanyak di puskesmas Kota Bandung dengan total jumlah pasien sebanyak 7654 jiwa. ${ }^{5}$

Pencegahan komplikasi DM adalah salah satu upaya petugas kesehatan untuk mengurangi angka morbiditas dan mortilitas DM. Tercatat pasien DM mengalami hipertensi (71\%), dislipidemia $(65 \%)$, retinopati $(28,5 \%)$, dan gangguan ginjal(44\%). Pasien DM sebanyak 1,8 kali lebih berisiko terkena serangan jantung dan 1,5 kali lebih berisiko terkena stroke. ${ }^{6}$ Pada tahun 2015 di Indonesia terjadi sebanyak 184.985 kematian yang disebabkan oleh penyakit DM. ${ }^{2}$

Penatalaksanaan DM terdiri dari 4 pilar yang terdiri dari konseling, terapi gizi medis, latihan jasmani, dan intervensi farmakologis. ${ }^{7}$ Program diet yang disertai dengan olahraga terbukti mengurangi risiko insidensi DM sebesar $58 \%{ }^{20}$ Konseling DM sebagai pilar pertama bertujuan memberikan edukasi komprehensif mengenai program diet dan olahraga agar pasien termotivasi untuk mengubah perilaku hidupnya menjadi lebih sehat.

Konseling terbukti memiliki efektivitas dalam meningkatkan kontrol gula darah pasien Diabetes Melitus Tipe 2 (DMT2). ${ }^{11,12}$ Peran konseling sangat penting dalam tatalaksana DM sehingga diperlukan standarisasi pemberian konseling DM oleh petugas kesehatan. Untuk memulai memberikan standarisasi pelayanan konseling diperlukan terlebih dahulu gambaran pelayanan konseling di layanan primer. Standar Kompetensi Dokter Indonesia dalam penatalaksanaan DMT2 adalah 4A, sehingga dokter umum harus dapat melakukan penatalaksanaan DMT2 sampai tahap terapi yang salah satunya adalah konseling. Mayoritas pasien diabetes belum menerima edukasi diabetes formal. ${ }^{13}$ Penelitian Ali dan Jusoff di Malaysia menunjukkan bahwa pasien tidak mendapat informasi mengenai penyakit DM beserta komplikasinya. ${ }^{14}$ Hasil ini konsisten dengan penelitian Abazari di Iran yang menunjukkan bahwa masih kurangnya pelayanan edukasi diabetes ditinjau dari segi kemampuan petugas kesehatan dalam memberikan konseling dan mengevaluasi keberhasilan konseling. ${ }^{15}$

Komponen konseling DM terdiri dari konseling gizi dan konseling olahraga. Pasien DMT2 yang diberikan intervensi program diet dan olahraga mengalami penurunan berat badan dan kadar glukosa darah yang lebih signifikan., ${ }^{9,10}$ Penelitian-penelitian konseling DM di Indonesia sebelumnya masih terfokus pada pelayanan konseling gizi sehingga belum banyak membahas konseling olahraga. Diabetes Melitus termasuk dalam 20 penyakit paling banyak di Puskesmas Kota Bandung, akan tetapi belum ada data mengenai pelayanan konseling DM. Berdasarkan hal tersebut perlu dilakukan penelitian untuk mengetahui gambaran pelayanan konseling gizi dan olahraga pada pasien DMT2 di Puskemas Kota Bandung.

\section{Metode}

Penelitian ini menggunakan metode deskriptif kualitatif menggunakan 24 sampel yang terdiri dari 3 dokter umum, 3 ahli gizi, dan 18 pasien DMT2. Penelitian ini dilakukan di tiga puskesmas Kota Bandung yang meliputi puskesmas Garuda, Puskesmas Pagarsih, dan Puskesmas Puter. Pemilihan puskesmas berdasarkan survei data prevalensi kasus DM di puskesmas kota Bandung oleh Dinas Kesehatan tahun 2015 yaitu puskesmas dengan prevalensi DM tertinggi, median, dan terendah di kota Bandung. Penelitian ini dilakukan mulai dari bulan Agustus hingga November 2016

Sampel penelitian menggunakan metode snowball sampling sampai data mencapai titik jenuh. Pasien yang datang untuk melakukan konseling masih tergolong minim karena rendahnya kesadaran pasien terhadap penyakit diabetes. Pasien diabetes yang memiliki kesadaran baik mengenai diabetes lebih sering berada dalam suatu komunitas misalnya seperti Prolanis (Program pelayanan penyakit kronis). Berdasarkan dari dua aspek tersebut, maka metode Snowball sampling memberi keuntungan dalam menemukan sampel penelitian yang masih berada dalam satu komunitas secara lebih cepat.

Sampel penelitian terdiri dari 2 kelompok. Kriteria inklusi kelompok pertama adalah petugas kesehatan (dokter umum dan ahli gizi) yang memberikan konseling gizi dan olahraga pada pasien DMT2 di Puskesmas Garuda, Puskesmas Pagarsih, atau Puskesmas Puter dan bersedia ikut serta dalam penelitian. Kriteria inklusi kelompok kedua adalah pasien DMT2 yang menerima konseling gizi dan olahraga di Puskesmas 
Garuda, Puskesmas Pagarsih, atau Puskesmas Puter dan bersedia ikut serta dalam penelitian. Kriteria eksklusi pasien DMT2 adalah pasien yang memiliki gangguan jiwa, pendengaran serta gangguan dalam berbicara.

Metode pengumpulan data menggunakan wawancara mendalam kepada dokter, ahli gizi, dan pasien DMT2 serta melakukan observasi saat proses konseling berlangsung. Teknik validitas data yang dilakukan berupa teknik triangulasi. Penelitian diawali dengan pengumpulan data, hasil dari wawancara dan observasi akan dibuat transkrip. Transkrip direduksi berdasarkan keterkaitannya terhadap topik penelitian. Hasil transkrip akan dikoding dengan cara mengolah informasi data tersebut menjadi segmen-segmen tulisan sebelum memaknainya dan dilanjutkan dengan kategorisasi. Hasil dari analisis data tersebut akan disajikan berupa teks narasi yang menggambarkan bagaimana konseling tersebut berlangsung. Perizinan etik sudah diajukan dan ditandatangani pada 30 Juni 2016 oleh Komisi Etik Penelitian Kesehatan Fakultas Kedokteran Universitas Padjajaran.

\section{Hasil}

Responden yang telah diwawancara berjumlah 24 orang dengan rincian 3 dokter umum, 3 ahli gizi, dan 18 pasien DMT2. Rincian daftar responden dapat di lihat di lampiran 1. Setelah dilakukan wawancara, observasi dilakukan di tiga puskesmas tersebut. Penelitian ini memiliki 2 tema besar yaitu pengetahuan dan pelayanan konseling yang terdiri dari konseling gizi dan konseling olahraga.

Pengetahuan; Pengetahuan mengenai penyakit DM meliputi definisi, penyebab, faktor risiko, diagnosis, tipe, dan komplikasi. Pengetahuan petugas kesehatan yang baik akan secara otomatis meningkatkan pengetahuan dan pemahaman pasien. Salah satu cara agar pasien menerima informasi ini adalah dengan konseling. Seluruh responden petugas kesehatan setuju bahwa konseling adalah hal yang penting bagi pasien. Proses konseling bertujuan untuk edukasi dan motivasi pasien agar glukosa darah pasien dapat terkontrol. Bahasa yang digunakan petugas kesehatan saat konseling sudah dirasa mudah dimengerti oleh pasien.

Berdasarkan wawancara ditemukan perbedaan pengetahuan dokter umum dan ahli gizi mengenai penyakit DM. Pengetahuan dokter umum mengenai penyakit DM meliputi definisi, penyebab, faktor risiko, diagnosis, tipe, dan komplikasi.Sedangkanpengetahuanahligizihanya meliputi definisi, faktor risiko, dan komplikasi
"Waah kalo penyakit DM mah lebih ke dokter neng, kalo bapak mah gizinya" (HM-ahli gizi)

Konseling bukanlah sesuatu yang mudah karena harus berusaha mengubah cara berfikir seseorang untuk mengubah perilaku hidupnya.

"Pertamanya kita gali dulu pengetahuan pasien sejauh apa, apa yang pasien tahu tentang DM. Baru setelah itu kita kasih tahu tentang penyakit DM itu apa, disebabkan oleh apa, jadi pasien akan sadar apa yang harus dilakukan agar gula darahnya terkontrol. Jika ada hambatan kita harus cari tahu masalahnya apa, supaya kita bisa carikan solusinya." (GC-dokter).

Konseling Gizi; Tahapan alur konseling gizi yang dilakukan di 3 puskesmas ini adalah berawal dari pendaftaran yang kemudian dilanjutkan dengan permeriksaan dokter di poli umum atau poli lansia. Jika ditemukan ada gejala DM, maka pasien diminta untuk melakukan pemeriksaan glukosa darah. Kemudian pasien akan kembali ke dokter. Setelah itu dokter merujuk pasien ke ahli gizi serta menyarankan pasien untuk mengikuti Prolanis.

Untuk sistematika wawancara dilakukan disesuaikan dengan alur konseling gizi yaitu Inisiasi, Melakukan Pengkajian Gizi, Menetapkan Diagnosis Gizi, Melakukan Intervensi Gizi, dan Monitoring dan Evaluasi.

Inisiasi; inisiasi dimulai dari proses perkenalan dan penjabaran tujuan konseling. Berdasarkan wawancara yang dilakukan di tiga puskesmas ini tahapan tersebut telah dilakukan.

"Kita bina suasana dulu, kita kondisikan senyaman mungkin. Kita lakukan proses pencairan dulu sehingga pasien datang ke tempat konseling itu dipastikan nyaman. Bina suasana itu ya kita saling menyapa, kenalan, kita tanya maksud dan tujuan kedatangannya. Kita ciptakan suasana yang akrab. Pertamanya saya jelaskan dulu tujuan dari konseling ini" ( HM-ahli gizi ).

Melakukan Pengkajian Gizi; Pengkajian gizi terdiri dari penilaian kebiasaan makan, aktivitas, umur, berat, dan tinggi badan pasien. Untuk pengkajian kebiasaan makan sehari-hari pasien telah dilakukan oleh petugas kesehatan. Pengukuran tinggi dan berat badan dilakukan oleh ahli gizi, sedangkan dokter biasanya hanya mengukur berat badan dan jarang mengukur tinggi badan.

"Awalnya dilakukan pengukuran tinggi badan dan berat badan.. Ini juga disesuaikan dengan usia dan aktivitas fisik. Kita tanya juga riwayat makan untuk mengetahui pola pola makan pasien sehari-hari"(HM-ahli gizi)

"Kita tanya makan apa saja, sebanyak apa, kapan saja makannya seperti itu. Kita gali terus kebiasaan makannya atau ngemil makanannya apa. Aktivitas fisik juga ditanya. 
Di sini kita timbang berat badan pasien, kalo untuk mengukur tinggi jarang kita lakukan" (Sendokter)

Menetapkan Diagnosis Gizi; Berdasarkan hasil pengkajian gizi maka ditetapkan diagnosis gizi sesuai dengan kebutuhan pasien. Berdasarkan wawancara yang dilakukan dari 24 responden, 18 responden menyatakan diagnosis gizi dilakukan oleh ahli gizi, sedangkan dokter tidak melakukan diagnosis gizi.

"Awalnya dilakukan pengukuran tinggi badan dan berat badan. Kita nilai indeks massa tubuhnya termasuk yang kekurangan, normal, atau berlebihan. Menghitung ini ada rumusnya, misalnya 20-30 kal/kg berat badan. Misalkan kebutuhan protein normal $15 \%$ dari kebutuhan energi total"(HM-ahli gizi)

"Kalo saya di sini tidak menghitung kebutuhan kalori pasien, kalo di ahli gizi mungkin dihitung dan lebih dalam penjelasannya karena ahli gizi biasanya meluangkan waktu lebih lama" (GCdokter).

Melakukan Intervensi Gizi; Tahapan Intervensi Gizi meliputi proses menginformasikan hasil pengkajian gizi, mendiskusikan perubahan pola makan, menjelaskan tentang penerapan anjuran makan untuk pasien DM. Untuk anjuran makanan dipilihkan dengan kebutuhan pasien dan tingkat ekonominya. Takaran makanan biasanya menggunakan ukuran rumah tangga agar dapat lebih dimengerti oleh pasien. Dokter dan ahli gizi menjelaskan tentang pilihan jenis makanan, jumlah makanan, dan jadwal makan. Ahli gizi memberikan penjelasan yang sangat spesifik seputar menu makanan, sedangkan dokter memberikan penjelasan bersifat umum yang lebih menekankan ke prinsip-prinsip anjuran makanan untuk pasien.

"Kalo saya kurang mendalami takaran gizi kalorinya, karena terkadang tidak selamanya pasien mengerti. Kalo di puskesmas rata-rata pasiennya menengah ke bawahjadi pendidikannya juga kurang, jadi kita penjelasannya yang mudah saja mana makanan yang dibatasi mana yang dihindari. Tapi kalo untuk lebih rinci dan spesifik pilihan makanan dan takarannya biasanya kita rujuk ke bagian gizi"(NCT-dokter).

Monitoring dan Evaluasi; Untuk mengetahui keberhasilan intervensi yang telah diberikan maka dokter atau ahli gizi harus menetapkan hasil yang diharapkan pada kunjungan berikutnya. Namun yang menjadi hambatan adalah mayoritas pasien hanya rutin kunjungan ulang ke dokter karena sekaligus untuk cek darah atau mengambil obat, sedangkan hanya sedikit pasien yang melakukan kunjungan ulang ke ahli gizi.

Rendahnya kunjungan ulang ke ahli gizi disebabkan oleh faktor keadaan pasien yang telah membaik atau pasien telah mengikuti Prolanis. Berdasarkan wawancara, mayoritas pasien telah memiliki kesadaran untuk mengikuti anjuran makanan dan melakukan perubahan hidup dikarenakan responden pasien merupakan pasien lama dan telah merasakan munculnya gejala. Sedangkan beberapa pasien lain mengaku masih ada hambatan dalam menjalankan anjuran makanan

Konseling Olahraga; Konseling olahraga diberikan pada pasien DMT2 oleh dokter dan ahli gizi. Tidak ada pedoman resmi tahapan konseling olahraga di Indonesia. Penjelasan olahraga secara definisi dan kaitannya terhadap penyakit DM belum banyak dilakukan oleh petugas kesehatan. Penjelasan mengenai olahraga hanya dilakukan oleh satu dari total 6 responden petugas kesehatan.

"Misal kita jelasin jalan ya bu, tapi jalannya jangan seperti jalan ke pasar karena itu bukan olahraga. Jadi jika kita hitung denyut nadinya kemudian ada peningkatan sebelum dan sesudahnya, maka itu yang disebut dengan olahraga" (NPT-dokter)

Berdasarkan wawancara 6 responden petugas kesehatan, hanya satu yang menjelaskan pengaruh olahraga ke tubuh pasien DM.

"Kalo menjaga pola hidup seperti pola makan dan berolahraga itu akan berefek ke hormon insulin. Walaupun insulinnya kurang, jika pasien berolahraga dan makannya bagus maka gulanya akan tidak banyak sehingga tidak meningkat kadar gula dalam tubuh" (Sen-dokter)

Seluruh responden pasien menyatakan bahwa mereka hanya diberikan intervensi olahraga berupa konten jenis, durasi, dan frekuensi olahraga tanpa adanya penjelasan mengenai definisi olahraga dan kaitannya terhadap DM. Intervensi Olahraga dilakukan setelah adanya pengkajian olahraga untuk menyesuaikan kebutuhan olahraga bagi pasien DMT2. Berdasarkan wawancara, jenis olahraga yang paling sering disarankan oleh dokter dan ahli gizi adalah berjalan kaki 20-30 menit minimal 2-3 kali seminggu. Kepatuhan pasien untuk berolahraga masih tergolong rendah. Ada beberapa faktor yang mempengaruhi kepatuhan olahraga pasien.

Berdasarkan observasi, fasilitas kesehatan berupa ruangan konseling dan food model telah tersedia di Puskesmas Garuda, Pagarsih, dan Puter.

\section{Pembahasan}

Penatalaksanaan DM di Indonesia terdiri dari 4 pilar meliputi konseling, terapi gizi medis, latihan jasmani, dan intervensi fakmakologis. ${ }^{7}$ Penelitian tentang efektivitas program konseling pada pasien 
DM sudah banyak dilakukan. Salah satunya di Amerika Serikat yang menunjukkan penurunan kadar glukosa darah yang signifikan pada pasien yang diberikan konseling dibandingkan dengan yang tidak diberikan konseling dengan nilai $p<0,01 .^{11}$ Hasil ini konsisten dengan penelitian lain di Taiwan. ${ }^{12}$ Berdasarkan hasil penelitian-penelitian di atas bisa disimpulkan bahwa konseling memiliki pengaruh yang besar pada pasien DMT2 jika dilakukan secara benar. Manfaat konseling juga dirasakan seluruh responden pasien pada penelitian ini berupa pengetahuan yang bertambah atau glukosa darah yang terkontrol.

Pengetahuan; Pengetahuan petugas kesehatan yang baik mengenai penyakit DM akan secara otomatis meningkatkan pengetahuan dan pemahaman pasien sehingga juga membantu untuk mengontrol glukosa darah pasien. ${ }^{17}$ Pengetahuan ahli gizi masih dikategorikan minim jika dibandingkan dokter yaitu meliputi definisi, faktor risiko, dan komplikasi. Penjelasan itupun masih bersifat superfisial. Perbedaan ini didasari persepsi ahli gizi yang menyatakan adanya pembagian ranah kerja seorang dokter dan ahli gizi. Seorang dokter memiliki ranah kerja seputar penyakit DM dan pengobatannya, sedangkan ahli gizi memiliki ranah kerja seputar gizi. Hal ini sesuai dengan penelitian Ali dan Jusoff yang menunjukkan bahwa pasien DMT2 tidak mendapat edukasi mengenai penyakit beserta komplikasinya. ${ }^{14}$ Penelitian lain oleh Abdulhadi menunjukkan masih rendahnya akses edukasi kesehatan dan petugas kesehatan yang kurang kompeten dari segi perspektif pasien diabetes. ${ }^{16}$ Penelitian Banu Hanifah Al Tera menunjukkan bahwa pengetahuan pasien mengenai penyakit DM merupakan salah satu faktor kepatuhan pasien yang dominan dalam menjalankan terapi gizi dan olahraga. ${ }^{19}$ Tingkat pengetahuan petugas kesehatan dalam memberikan konseling dapat dipengaruhi oleh riwayat pelatihan edukasi DM. Berdasarkan wawancara seluruh responden petugas kesehatan menyatakan belum pernah mengikuti pelatihan edukasi DM.

Konseling Gizi; Konseling gizi yang dilakukan pada pasien DMT2 di puskesmas Garuda, Pagarsih, dan Puter secara umum sudah sesuai dengan pedoman PERKENI dan PERSAGI yang meliputi proses inisiasi, pengkajian gizi, diagnosis gizi, intervensi gizi, dan evaluasi. ${ }^{7,8}$ Kemudian dari segi fasilitas meliputi ruangan dan food model juga telah tersedia di ketiga puskesmas tersebut. Akan tetapi konseling yang diberikan oleh ahli gizi dan dokter ternyata memiliki beberapa perbedaan dalam hal tahapan konseling. Dalam tahapan pengkajian gizi, ahli gizi melakukan pengukuran berat dan tinggi badan, sedangkan mayoritas dokter hanya mengukur berat badan dan jarang melakukan pengukuran tinggi badan. Jika ditelusuri lebih jauh hasil pengukuran ini akan dihitung untuk melakukan diagnosis gizi. Mayoritas responden menyatakan bahwa dokter tidak melakukan penetapan diagnosis gizi dan hanya ahli gizi yang melakukan penetapan diagnosis gizi. Tanpa adanya diagnosis gizi maka akan berpengaruh pada pemilihan jenis dan jumlah makanan yang dianjurkan. Penjelasan anjuran makan yang spesifik hanya dilakukan oleh ahli gizi, sedangkan dokter hanya menjelaskan prinsip prinsip pola makan secara general.

Dokter umum di ketiga puskesmas ini memiliki rata-rata jumlah pasien sekitar 100-200 pasien per hari. Untuk di poli lansia rata-rata sekitar ada 40 pasien per hari. Waktu pelayanan biasanya adalah dari pukul 08.00-11.30 pagi. Ini berarti ada sekitar 6 menit untuk satu pasien. Melihat dari minimnya waktu yang tersedia menyebabkan dokter tidak sempat menjelaskan anjuran makan yang mendetail ditinjau dari pilihan, jumlah, dan jadwal makan. Hal ini menyebabkan dokter tidak melakukan diagnosis gizi. Jikapun ada waktu, maka kemampuan diagnosis gizi dokter masih sangat kurang karena tidak biasa melakukan perhitungan sebelumnya. Hal ini sesuai dengan penelitian Parvaneh Abazari dan Banu. ${ }^{15,19}$ Kemudian faktor usia yang tua dan tingkat pendidikan pasien yang sebagian besar masih rendah juga menyebabkan dokter merasa tidak perlu untuk memberikan penjelasan detail yang dirasa dapat menyulitkan pasien untuk mengerti. Dokter akan melakukan rujukan ke ahli gizi jika pasien ingin mendapatkan penjelasan yang lebih mendetail.

Jika dilihat dari kedua permasalahan tersebut, dapat disimpulkan adanya missing link dari penatalaksanaan konseling gizi di puskesmas Kota Bandung. Dokter umum tidak dapat melakukan diagnosis dan intervensi gizi secara mendetail, sedangkan ahli gizi tidak dapat menjelaskan penyakit DM secara mendetail. Hal ini didukung oleh penelitian Parvaneh Abazari di Iran yang menujukkan kurangnya pelayanan edukasi diabetes yang ditinjau dari segi kemampuan petugas kesehatan dalam memberikan konseling dan mengevaluasi keberhasilannya. ${ }^{15}$ Penelitian lain oleh Adzani menunjukkan hanya satu atau dua dari lima klinik kesehatan di Kuwait yang menyediakan edukasi bagi pasien DM, akan tetapi edukasi tersebut juga masih tidak terstruktur atau terintegrasi dengan program pengobatan penyakit diabetes melitus di klinik tersebut. ${ }^{17}$

Berdasarkan wawancara dari 18 pasien DMT2, 13 pasien menyatakan telah mematuhi anjuran makan karena telah menyadari pentingnya merubah pola hidup. Kesadaran 
pasien dipengaruhi oleh lama pasien memiliki $\mathrm{DM}$, munculnya gejala, afeksi terhadap penyakit, faktor genetik, dan komplikasi. Pasien yang telah lama memiliki DM dan menganggap DM adalah suatu masalah yang disertai dengan munculnya gejala DM, faktor genetik, dan komplikasi memiliki tingkat kesadaran untuk mengubah perilaku sehingga tingkat kepatuhannya akan lebih tinggi. Hanya ada beberapa hambatan yaitu dari faktor keluarga, nafsu makan, usia lansia, dan persepsi takut sakit jika makan sedikit.

Konseling Olahraga; Penatalaksanaan konseling olahraga di Indonesia belum memiliki pedoman khusus. Akan tetapi dari segi konten konseling olahraga berdasarkan PERKENI 2015 disarankan untuk berolahraga 3-5 kali perminggu selama sekitar 30-45 menit, dengan total 150 menit perminggu. Jeda antar latihan tidak lebih dari 2 hari berturut-turut. Olahraga yang dianjurkan berupa olahraga yang bersifat aerobik dengan intensitas sedang (50-70\% denyut jantung maksimal) seperti jalan cepat, bersepeda santai, jogging, dan berenang. Pada penderita DM tanpa komplikasi juga disarankan untuk melakukan resistance training (latihan beban) 2-3 kali/perminggu. Jenis dan intensitas olahraga sebaiknya disesuaikan dengan umur dan status kebugaran jasmani pasien. ${ }^{7}$ Penelitian Loreto menunjukkan ada 7 protokol dalam konseling olahraga yang harus dilakukan agar terdapat perubahan signifikan dalam pengontrolan glukosa darah pasien. ${ }^{10}$ Ketujuh protokol tersebut meliputi motivasi, efikasi diri, rasa senang, dukungan orang terdekat, komprehensif, solutif, dan evaluasi. Jika dibandingkan dengan 7 protokol ini, maka konseling olahraga di puskesmas Garuda, Pagarsih, dan Puter memenuhi protokol Efikasi Diri dan Rasa Senang dalam proses pengkajian olahraga sehingga olahraga yang disarankan sesuai dengan kebutuhan pasien. Setelah proses pengkajian olahraga dilakukan intervensi olahraga yang secara mayoritas disarankan untuk berjalan kaki 30 menit minimal 3 kali seminggu mengingat usia pasien yang mayoritas tua. Penjelasan mengenai definisi olahraga dan kaitannya terhadap penyakit DM belum banyak dilakukan oleh petugas kesehatan pada konseling olahraga. Di ketiga puskesmas ini tidak terdapat banyak perbedaan konten konseling olahraga bagi pasien DM dengan dan tanpa komplikasi. Jenis olahraga bagi pasien komplikasi tetaplah sama hanya durasi dan intensitasnya yang dikurangi sesuai dengan kemampuan pasien. Padahal berdasarkan American Diabetes Association (ADA) terdapat perbedaan signikan pilihan olahraga untuk pasien dengan dan tanpa komplikasi. ${ }^{20}$ Kepatuhan pasien terhadap anjuran olahraga masih rendah dikarenakan hambatan berupa usia yang tua sehingga sudah malas untuk bergerak,adanya komplikasi atau penyakt lain, tidak memiliki teman untuk berolahraga, pasangan hidup yang telah meninggal, dan tidak adanya waktu berolahraga. Rendahnya pengetahuan, sikap, dan latihan pasien DM untuk berolahraga atau berjalan kaki sesuai dengan hasil penelitian Shamsi di India Selatan sehingga diperlukan program edukasi olahraga khusus untuk mengontrol gula darah pasien. ${ }^{18}$

Limitasi dalam penelitian ini adalah kelemahan metode snowball sampling sehingga pasien pasien yang menjadi responden hanya pasien yang mengikuti program Prolanis (Program Pengelolaan Penyakit Kronis), sedangkan pasien DM yang tidak mengikuti program prolanis belum bisa berpartisipasi dalam penelitian ini.

Pengetahuan dokter mengenai penyakit DM lebih lengkap dibandingkan ahli gizi. Proses konseling gizi oleh ahli gizi berjalan sesuai dengan standar meliputi inisiasi, pengkajian, diagnosis gizi, intervensi, dan evaluasi. Berdasarkan dari 24 responden, 18 responden menyatakan konseling gizi oleh dokter dilakukan tanpa tahapan diagnosis gizi. Konseling olahraga meliputi pengkajian dan intervensi olahraga yang dilakukan memenuhi 2 dari 7 protokol konseling olahraga. Fasilitas konseling meliputi ruangan dan food model telah tersedia di Puskesmas Garuda, Pagarsih, dan Puter.

Rekomendasi untuk Dinas Kesehatan Kota Bandung adalah untuk melakukan pelatihan edukasi DM untuk dokter dan ahli gizi agar ilmuilmu yang baru dapat diterapkan oleh petugas kesehatan sehingga pelayanan konseling gizi dan olahraga di Puskesmas Kota Bandung dapat lebih maksimal.

\section{Daftar Pustaka}

1. Olokoba AB, Obateru OA, Olokoba LB.Type 2 Diabetes Mellitus: A review of Current Trends. Oman Medical Journal.2012;27(4):269-273.

2. International Diabetes Federation (IDF). IDF Diabetes Atlas Seventh Edition, International Diabetes Federation (IDF). 2015

3. Ramachandran A, Snehalatha C, Shetty AS, Nanditha A. Trends in Prevalence of Diabetes in Asia Countries. World Journal Diabetes. 2012; 3(6): 110-117.

4. Pusat Data dan Informasi Dinas Kesehatan Kota Bandung Tahun 2015 (Laporan LB1 Kabupaten/Kota Kota Bandung per Kategori per Puskesmas). 2015. Dinas Kesehatan Kota Bandung; 2015.

5. Pusat data dan Informasi Dinas Kesehatan 
Kota Bandung Tahun 2012 (Profil Kesehatan Kota Bandung). 2012. Dinas Kesehatan Kota Bandung; 2012

6. American Diabetes Association (ADA). Statisitic About Diabetes, American Diabetes Association (ADA). 2016

7. Perkumpulan Endokrinologi Indonesia. Konsensus Pengendalian dan Pencegahan Diabetes Melitus Tipe 2 di Indonesia. 2015: 17-27

8. Persatuan Ahli Gizi Indonesia Konseling Gizi. Proses Komunikasi, Tata laksana, serta Aplikasi Konseling Gizi di Berbagai Diet. 2013: 50-63

9. Colberg S, Sigal R, Fernhall B. Exercise and Type 2 Diabetes. The American College of sports Medicine and The American Diabetes Association : joint position statement. Diabetes Care Journal. 2010; 33:147-167.

10. Loreto C, Fanelli C, Lucidi P, et al. Validation of a Counseling Strategy to Promote the Adoption and the Maintenance of Physical Activity by Type 2 Diabetic Subjects. Diabetes Care Journal. 2003; 26: 404-408.

11. Sullivan S, Dalal M, Burke. The Impact of Diabetes Counseling and Education : Clinical and Cost Outcomes From a Large Population of US Managed Care Patients With Type 2 Diabetes. 2013; 39 (4).

12. Huang M, Hsu C, Huan-Sen, Wang H, Shin S. Prospective Randomized Controlled Trial to Evaluate Effectiveness of Registered Dietitian-Led Diabetes Management on Glycemic and Diet Control in Primary care Setting in Taiwan. Diabetes Care Journal. 2010;33:233-239.

13. Funnel MM, Brown TL, Childs BP. National
Standards for Diabetes Self Management Education. Diabetes Care. 2009;32(Suppl 1):S87-S94.

14. Mohd Ali S, Jusoff K. Barriers to optimal control of type 2 diabetes in Malaysian Malay patients. Glob J of Health Sci.2009;1:106118.

15. Abazari P, Vanaki Z, Mohammadi E, Amini $M$ : Inadequate investment on management of diabetic education. Journal of Research in Medical Sciences: The Official Journal of Ishafan University of Medical Sciences 2012; 17(8):792-798.

16. Abdulhadi N, Al Shafaee M, Freudenthal S, Ostenson CG, Wahlstrom R. Patientprovider interaction from the perspectives of type 2 diabetes patients in Muscat, Oman:A qualitative study.BMC Health Serv Res. 2007;7:162

17. Al-Adsani A, Al-Faraj, Al-Sultan F, El-Feky M, Al-Mezel N, Saba W, et al. Evaluation of impact of the Kuwait Diabetes Care Program on the quality of diabetes care. Med Princ Pract.2008;17:14-9

18. Shamsi M, Sharifi Rad GH, Kachoei A, Hasan Zadeh A, Dejham S. Knowlegde, attitude and practice of women by type 2 diabetes about walking. Payesh Journal.2011;10:477-84.

19. Tera BHA, Noer ER. Determinan Ketidakpatuhan Diet Penderita Diabetes Melitus Tipe 2 di Wilayah Kerja Puskesmas Srondol Kota Semarang. Semarang : Universitas Diponegoro; 2011.

20. Sigal RJ, Kenny GP, Wasserman DH, Castaneda C, White RD. Physical Activity/ Exercise and Type 2 Diabetes. Diabetes Care Journal. 2006; 29 (6) : 1433-1438. 